\title{
Empirical Evidence for Models to Estimate the Cost of Equity Capital
}

\author{
Eliseu Martins * \\ USP - University of São Paulo \\ Fernando Caio Galdi * \\ USP - University of São Paulo
Gerlando Augusto Sampaio Franco de Lima ${ }^{\dagger}$
USP - University of São Paulo
George Anthony Necyk *
USP - University of São Paulo
Cesar Henrique Shogi Abe ${ }^{\Psi}$
USP - University of São Paulo

\begin{abstract}
This article investigates whether there are statistically significant differences among the costs of equity capital of Brazilian companies estimated by four models and their variants: Gordon, CAPM, APM and Ohlson-Juettner. We used a cross-section of 34 companies that were part of the São Paulo Stock Exchange Index (IBOVESPA) on December 29, 2005. The results do not permit saying that the choice of model makes no difference in estimating the cost of equity capital, so the methodology hypothesis was rejected. The models based on profit and dividend projections, notably the OJ and Gordon models, resulted in equivalent mean values and also were those that most resemble each other. The OJ model appears to be theoretically superior to the Gordon and Gordon \& Gordon models, given that it was developed with fewer premises and in a more analytic manner.
\end{abstract}

Keywords: company valuation, cost of equity capital, difference of means test.

Received in 08/15/2006; revised 10/03/2006; accept in 11/02/2006.

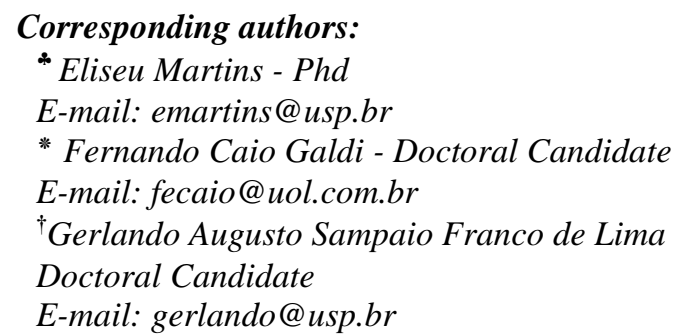

¥ George Anthony Necyk-Doctoral Candidate

E-mail: gnecyh@msbrasil.com.br

${ }^{\Psi}$ César Herinque Shogi Abe-Doctoral Candidate

E-mail: cesarabe@yahoo.com

Editor's note: This paper was accepted by Alexsandro Broedel Lopes. 


\section{INTRODUCTION}

$\mathrm{O}$ ne of the most important steps in the process of valuing companies, mainly those listed on stock exchanges, is to measure their cost of equity capital. Much of the importance of adequate estimation of this variable rests in the sensitivity of the valuation models to changes in the discount rates employed ${ }^{1}$.

The concept of cost of equity capital, although widespread, has subjective characteristics because it is not a directly observable variable. For companies with many shareholders and potential future shareholders, it is not possible to know exactly what return they require on their investments. Therefore, several models have been developed to ascertain, within the premises of economic rationality, what a determined company's cost of equity capital is.

In order to compare the methods for estimating this variable, this work investigates whether there are statistically significant differences among the equity capital costs estimated for Brazilian companies through the following models: i) Gordon model; ii) capital asset pricing model (CAPM); iii) arbitrage pricing model (APM); and iv) Ohlson-Juettner model (OJ).

The next section explains these models briefly, then Section 3 discusses the design of the study and the sample used, and Section 4 presents the results. Section 5 concludes.

\section{ESTIMATION MODELS}

The models used in this study are quite widespread in the financial and accounting literature $^{2}$ and each of them, evidently, has advantages and disadvantages in relation to the others. Below we briefly present each of these models' formulations.

\subsection{The Gordon Model}

The classic model of Gordon (1962), also known as the dividend discount approach, proposes that a stock's expected return is given by the discount rate, which equals the current share price with the expected future dividend flow, according to the formula below:

$$
P_{0}=\sum_{t=1}^{\infty} \frac{d p s}{(1+r)^{t}}
$$

where $P_{0}$ is the current share price; $d p s_{t}$ is the expected dividend per share at date $t$; and $r$ is the equity capital cost.

\footnotetext{
${ }^{1}$ Normally one of the main components of calculating the discount rate in valuation models is the cost of equity capital.

2 Examples include Bernstein and Wild (1997), Copeland et al. (2000), Damodaran (1997), Palepu et al. (2004), Penman (2001), White et al. (2003), Ross et al. (1995) and Iudícibus and Lopes (2004).
} 
Using the premise that the expected future dividend flow can initially be represented by the expectation for the next period and that the growth rate of the dividends for the periods thereafter is constant, the formula above reduces to:

$$
P 0=\sum_{t=1}^{\infty} \frac{d p s_{1} \times(1+g)^{t-1}}{(1+r)^{t}}=\frac{d p s_{1}}{r-g}
$$

where $g$ is the expected constant dividend growth rate.

From this expression, the equity capital cost it given by:

$$
r=\frac{d p s_{1}}{P_{0}}+g
$$

Gordon (1993) suggested that this approach be operationalized by substituting the expected growth rate of profits for the expected dividend growth rate, which is only appropriate when the dividend-share price ratio is constant over time. This premise is frequently violated.

The main shortcomings of the above approach are the hypothesis of constant dividend growth and the direct relationship between dividends and profits. Gordon and Gordon (1997) tried to circumvent this drawback by developing a variation of the original Gordon model with a finite horizon.

Various authors have argued that a firm cannot expect high or low growth forever. Thus, there is a finite number of periods in which growth can be abnormal, after which it is assumed that the shareholder will be content to receive the equivalent of the return on equity. With these premises, which are less restrictive than the previous ones, the improved equation considering the possibility of differentiated growth of the future dividend flows becomes:

$$
P_{0}=\sum_{t=1}^{T}-d p s_{t}(1+r)^{t}+\frac{e p s_{t+1}}{r(1+r)^{t+1}}
$$

where $t$ is the number of periods for which abnormal growth is expected and eps $(t+1)$ is the earnings per share in period $t+1$ (the period when earnings growth stops being abnormal).

Gordon and Gordon (1997) suggested that the definition of $n$ should follow the horizon that analysts use for their projections, which is roughly five years. Thereafter, they pointed out, the consensus of opinion among analysts deteriorates rapidly. Hence, they concluded that a value of $n$ between five and ten is reasonable. However, subsequent studies have used shorter horizons, such as Botosan and Plumlee (2001), who used $n$ equal to three.

\subsection{The Capital Asset Pricing Model (CAPM)}

The capital asset pricing model is an economic model used to value bonds, by relating risk and return. Its formulation originated from the initial idea of Markowitz (1952) that an investment decision is limited to the combination of investing or funding at a risk free rate plus the premium offered by the market portfolio (ARAÚJO, p.15).

Sharpe and Treynor, cited in Araújo (1996, pp. 21-22), concluded that the risk measured by variance is composed of systematic risk (which is correlated with the total portfolio risk) 
and non-systematic risk (which can be eliminated by diversifying the portfolio). The systematic risk, called beta, is measured by the covariance between the variation in the particular share price in relation to the mean variation of all share prices.

The CAPM can be used to measure the expected return (cost of capital) of a security individually and to measure the expected return of a portfolio of assets. However, in both cases, the CAPM assumes the basic hypothesis that the premium to the investor is determined by the systematic risk. The CAPM equation is represented as follows:

$$
r_{\mathrm{pt}}=r_{\mathrm{ft}}+\beta_{\mathrm{p}} \delta_{1}
$$

where: $r_{\mathrm{pt}}$ is the expected return (cost of capital) of portfolio $\mathrm{p}$ (or asset $\mathrm{p}$ ) in time period $\mathrm{t} ; \beta_{\mathrm{p}}$ is the systematic risk of portfolio $\mathrm{p}$ (or of the asset in relation to the market risk), given that $\operatorname{Cov}\left(r_{\mathrm{pt},}, r_{\mathrm{mt}}\right) / \operatorname{Var}\left(r_{\mathrm{mt}}\right) ; \delta_{1}$ is $\left(r_{\mathrm{mt}}-r_{\mathrm{ft}}\right) ; r_{\mathrm{mt}}$ is the market return (or the return on an appropriate class of assets) in period $\mathrm{t}$; and $r_{\mathrm{ft}}$ is the return of a risk-free asset in period $\mathrm{t}$;

Normally the risk-free asset is represented by public bonds and the market return by an index that represents the trading occurring in a secondary market, because it would be impractical to include all risky assets in the economy and evaluate their respective weightings (GREGÓRIO, p. 50).

In Brazil the index most often used as a proxy for trading in the secondary market is the São Paulo Stock Exchange Index (IBOVESPA), which reflects the evolution of stock prices, and for the risk-free rate of return the SELIC rate (System for Settlement and Custody of Public Securities) (GREGÓRIO, pp. 50 and 51) ${ }^{3}$.

However, because of the peculiar characteristics of the Brazilian market (Brazilian sovereign debt cannot be considered totally risk free, mainly because the country has declared moratoriums twice in its history, and there is no index that adequately represents the model's assumptions), the CAPM cannot be used solely with Brazilian indices.

Therefore, besides the CAPM with Brazilian indices, we use American indices as well, adapted to Brazilian reality by the country risk. The risk-free return considered here, then, corresponds to that on U.S. Treasury Bonds, and for the market rate we used the Standard \& Poor's (S\&P) 500, corresponding to the 500 most-traded shares on the New York Stock Exchange (NYSE).

\subsection{The Arbitrage Pricing Model (APM)}

According to Reilly and Brown (2003), at the start of the 1970s there was a search for a new pricing model to serve as an alternative to the CAPM and that would have more flexible theoretical assumptions and greater efficiency in verification and practical prediction of market returns. The result was the arbitrage pricing model (APM).

According to the APM, the rate of return of securities consists of two parts: one is the normal or expected return, and the second is the uncertain or unexpected return. This second portion is determined by information or news that is hard to forecast, but can naturally occur in a period. Therefore, any announcement can be decomposed into expected or anticipated news on the one hand and unexpected news, surprises or innovations on the other. It is possible, then, to decompose these "unexpected pieces of news" (or risk) in two ways, one

\footnotetext{
${ }^{3}$ Nevertheless, in this work we use the IBrX as a proxy, because it considers the market more broadly. Besides this, since the SELIC rate corresponds to the basic interest rate in the economy instead of the yield on a particular bond, we use as a proxy for the risk-free rate of return that on the Brazilian government's C-Bond, subsequently exchanged for the A-Bond.
} 
called systematic risk and the other non-systematic risk. As defined by Ross, Westerfield and Jaffe (2002):

- Systematic risk is any risk that affects a large number of assets, each of them with greater or lesser intensity.

- Non-systematic risk is risk that specifically affects one security or a small group of them.

With this formulation, the return on a security consists of the interest rate on risk-free investments complemented by a risk premium, but the calculation of the return is influenced by macroeconomic factors that affect securities prices in general, such as the level of economic activity, basic interest rate, oil price and exchange rate, among others.

With this, according to Martins (2001, p. 213), "since the risk is decomposed by macroeconomic factors, the expectation is for the $\beta$ 's of the APM to be more appropriate than the generic CAPM measure."

Therefore, the return on securities by this model is determined by the equation:

$$
R=\bar{R}+m+\varepsilon
$$

where $R$ is the observed return in the period, $\bar{R}$ is the expected portion of this return, $m$ is the systematic risk, and $\varepsilon$ is the company-specific risk, which is not related to the specific risk of other companies.

For each risk there is a beta coefficient, $\beta$, which tells us the reaction of an asset's rate of return to a systematic risk. The systematic sources of risk are called factors and can be designated by $F$. Thus, the model for each asset is designated by:

$$
R=\bar{R}+\beta_{1} F_{1}+\beta_{2} F_{2}+\ldots+\beta_{n} F_{n}+\varepsilon_{i}
$$

where $R$ is the observed rate of return in the period, $\bar{R}$ is the expected portion of this return, $\beta$ is the coefficient that determines the reaction of the rate of return to each systematic risk, and $\varepsilon$ is the company-specific risk.

Condensing equation 7 , which represents the yield of an individual security according to diverse factors, and transforming it into a single factor gives:

$$
R_{i}=\bar{R}_{i}+\beta_{i} F+\varepsilon_{i}
$$

Besides concern over the factors that will be used explicitly in the APM, the model makes the following theoretical assumptions:

1. The returns are generated according to a linear model of factors.

2. The number of securities tends to infinity.

3. Investors have homogenous expectations.

As can be seen, the model has an expected risk premium that depends on a calculated factor along with the sensitivity of the yield in relation to each beta factor. With this, the equation for the risk premium of a particular stock is the following: 
Risk premium of share $\mathrm{i}=\beta_{\mathrm{i} 1}\left(\mathrm{r}_{\mathrm{factor} 1}-\mathrm{r}_{\mathrm{f}}\right)+\beta_{\mathrm{i} 2}\left(\mathrm{r}_{\mathrm{factor} 2}-\mathrm{r}_{\mathrm{f}}\right)+\ldots+\beta_{\mathrm{ik}}\left(\mathrm{r}_{\text {factork }}-\mathrm{r}_{\mathrm{f}}\right)$

Finally, to calculate the cost of equity capital, the risk premium of the share is added to the yield of a risk-free asset, as follows:

Cost of equity capital $=$ Risk premium of the share $+R_{f}$

Several measures can be used for the risk-free return, such as the rate paid on guaranteed passbook savings accounts, the rate of Brazilian sovereign bonds or the rate paid on 10-year American Treasuries.

In tests with Brazilian data, Garcia and Bonomo (2001) used the yield of a market portfolio and an unexpected inflation component, and indirectly the interest rates prevailing in the economy. Schor, Bonomo and Pereira (2002) employed industrial output, inflation, credit risk, real interest rate and market portfolio return (obtained from the residuals of the extra return of the IBOVESPA in relation to the inter-bank certificate of deposit rate). Nakamura and Camargo JR (2002a and 2002b), using factorial analysis, obtained factors representing : (1) economic performance; (2) unemployment; (3) inflation; (4) exchange rate; (5) foreign exchange reserves; (6) IBOVESPA/bank CD; and (7) current transactions in relation to GDP.

In this work we use the following factors: (1) oil prices (Brent FOB and WTI FOB), (2) return of the particular stock; (3) overall market returns (IBOVESPA, IBrX, Dow Jones), (4) inflation, (5) exchange rate between the Brazilian Real and the dollar; and (6) inter-bank deposit rate.

One of the problems encountered in the mathematical formulation of the APM is that there is no econometric theory that says which factors can be correlated in the observed equation. Hence, there is a need to verify if the equation really identifies all the desired factors. Despite this, the APM has the advantage of not depending only on just the overall market, as does the CAPM.

\subsection{The Ohlson-Juettner (OJ) Model}

In a recent article, Ohlson and Juettner-Nauroth (2005) developed a model in which the expected earnings per share $(e p s)^{4}$ and its subsequent growth determine a company's value. Among the positive points of this model is its practical applicability and generalization of the constant dividend growth model of Gordon. The model assumes that the net present value of future dividends per share $(d p s)$ determine the price, but it does not impose restrictions on how the expected $d p s$ sequence should evolve (as for example the Gordon model, which assumes constant dividend growth and a homogenous relation between $d p s$ and eps). Additionally, Ohlson and Juettner-Nauroth (2005, p.350) commented:

In fact, the model is based on an assumption that the current price does not

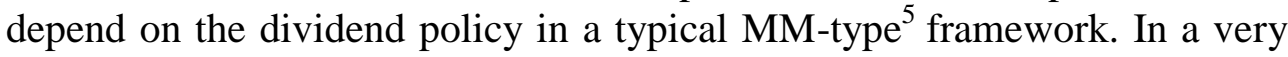
real sense, the core of the model shows how the current price depends on forward eps and their subsequent growth as captured by two dividend-policy independent measures of growth.

\footnotetext{
${ }^{4}$ In this work we use the nomenclature originally presented by Ohlson and Juettner-Nauroth (2005) in order to present their concepts uniformly.

5. [Modigliani and Miller].
} 
The OJ model determines a company's value as a function of the eps of the next period, the short-term growth of the eps, the long-term growth of the eps and the cost of capital.

To present the OJ model, it is first necessary to discuss the model developed by Ohlson (2005), called abnormal earnings growth (AEG). Ohlson (2005) demonstrates that:

$$
P_{0}=\frac{e p s}{r}+\sum_{t=1}^{\infty} R^{-t}\left(z_{t}\right)
$$

where: ${ }_{t}^{z}={ }_{r}^{1}\left[{ }^{\text {eps }}{ }_{t+1}+r d p s_{t}-\operatorname{Reps}_{t}\right] ; R=(1+r) ; P_{0}$ is the current price per share $(\mathrm{t}=0) ;$ eps $_{l}$ is the earnings per share expected on date $t=1 ; e p s_{t+1}$ is the earnings per share expected on date $t+1 ; d p s_{1}$ is the dividend per share expected on date $t=1$ and $r$ is the cost of equity capital.

Hence, equation 11 shows that the present value of the sequence $z_{t}$ represents the valuation premium, $P_{0}-e p s 1 / r$. Ohlson and Juettner-Nauroth (2005) reported that $z_{t}$ can be interpreted by thinking of $r z_{t}$, as if it were a measure of expected performance for the period $(t, t+1)$.

Thus $r z_{t}=\left[e p s_{t+1}-\left(\operatorname{Reps}_{t}-r d p s_{t}\right)\right],\left(\operatorname{Reps}_{t}-r d p s_{t}\right)$ is a type of benchmark for the expected eps for the period $(t, t+1)$. If $z_{t}=0, P_{0}=e p s 1 / r$. Hence, $z_{t}>0$ represents the expectation of better earnings per share performance measured by the changes in the eps adjusted by the retained earnings. To investigate the meaning of $z_{t}$ and get an initial picture of the neutral impact of the dividend policy (under a given premise) on the share price, one can consider the following situations:

1. Payout ${ }^{6}$ of 100\%: in this situation, $r z_{t}=\Delta e p s_{t+1}$, so $z_{t}=0$ if and only if eps $s_{t}=e p s_{t+1}$, i.e., if there is no expected growth in the earnings per share, and thus $P_{0}=e p s_{1} / r$.

2. Payout of 0\%: in this situation, $r z_{t}=e p s_{t+1^{-}} \operatorname{Reps}_{t}$, so $z_{t}=0$ if and only if $\Delta e p s_{t+1} /$ eps $s_{t}$ $=r$, i.e., if the expected growth in earnings per share is equal to the cost of capital, and thus $P_{0}=e p s 1 / r$.

It is not intuitively evident that a company's dividend policy does not influence its stock price, but Ohlson and Juettner-Nauroth (2005) demonstrate that in their model this is indeed the case, because $\partial z_{t+\tau} \partial d p s_{t}=0$ for all $\tau \geq 0$ if and only if $\partial e p s_{t^{+}} / \partial d p s_{t}=-r R^{\tau-1}$. This means that one additional Real distributed in dividends today fails to produce $\mathrm{R} \$ r R$ (as financial revenue) for the company in the next period, $\mathrm{R} \$ r R^{2}$ in the next, and so forth. Under this condition, the dividend policy does not affect $z_{t}$.

The model's second premise is that the sequence $\{z t\}_{t=1}^{\infty}$ satisfies the following condition: $z_{t+1}=\gamma z_{t}, \quad t=1,2,3, \ldots$, where $1 \leq \gamma \leq R$ and $z_{1}>0$.

Thus, under the premise that the present value of the expected dividends per share equals the value of one share and that the sequence $\{z t\}_{t=1}^{\infty}$ evolves positively, they develop the model so that the cost of capital can be represented by:

$$
r=\frac{1}{2}\left(\gamma-1+\left.\frac{d p s_{1}}{P_{0}}\right|_{j}+\sqrt{\frac{1}{2}\left(\gamma-1+\frac{d p s_{1}}{P_{0}}\right)^{2}+\frac{e p s_{1}}{P_{0}} \times\left(\frac{\Delta e p s_{2}}{e p s_{1}}-(\gamma-1)\right)}\right.
$$

It is interesting to note that although equation 12 appears to be complex, it only depends on the following variables: current price per share; dividend per share expected at the end of

\footnotetext{
${ }^{6}$ Ratio between dps and eps.
} 
period 1, earnings per share expected at the end of period 1, the expected earnings growth in period 1 in relation to period 2 and the parameter $\gamma$.

\subsection{Summary of the Advantages and Disadvantages of the Models Presented}

Table 1 presents a summary of the pros and cons of the methods presented.

Table 1: Advantages and Disadvantages of the Models

\begin{tabular}{|c|c|c|}
\hline Model & Advantages & Disadvantages \\
\hline Gordon & $\begin{array}{l}\text { 1. Ease of understanding and } \\
\text { implementation (simple model). }\end{array}$ & $\begin{array}{l}\text { 1. Premise of fixed dividend distribution growth (simple } \\
\text { model) is unrealistic in practice (BOTOSAN and } \\
\text { PLUMLEE, 2000, p13). } \\
\text { 2. Premise that the expected return to the shareholders after a } \\
\text { period of abnormal growth (extended model) will always } \\
\text { be equivalent to the return on equity is also not always the } \\
\text { case in practice (BOTOSAN and PLUMLEE, 2000, p13). } \\
\text { 3. Quite simple hypotheses regarding the future behavior of } \\
\text { companies (MARTINS, 2001, p. 212). } \\
\text { 4. Since this model (extended) was developed ex post facto, } \\
\text { without analytic formulation and without a closed } \\
\text { response, it must be resolved by numerical means } \\
\text { (BOTOSAN and PLUMLEE, 2000, p 13). }\end{array}$ \\
\hline CAPM & $\begin{array}{l}\text { 1. Most widespread model in the } \\
\text { market. } \\
\text { 2. Has strong economic } \\
\text { grounding. }\end{array}$ & $\begin{array}{l}\text { 1. According to Roll (1997), the model cannot be tested } \\
\text { empirically, since it is not possible to know the expected } \\
\text { return of the market portfolio, which must represent all } \\
\text { assets in the economy. Schor, Bonomo and Pereira ( } 2004 \text {, } \\
\text { p. 55) argue that "it is impossible to observe the market } \\
\text { portfolio, and the real hypothesis verified in the tests } \\
\text { proposed for the CAPM is not the hypothesis of Sharpe.". } \\
\text { 2. Subjectivity in the estimation of the expected market } \\
\text { portfolio return. } \\
\text { 3. The premise of an efficient market is widely criticized } \\
\text { nowadays. }\end{array}$ \\
\hline APM & $\begin{array}{l}\text { 1. Addition of more factors that } \\
\text { influence the return of the } \\
\text { securities than the CAPM. } \\
\text { 2. Intuition of the model similar to } \\
\text { that of CAPM. } \\
\text { 3. Does not need hypotheses on } \\
\text { the distribution of earnings per } \\
\text { share or the structure of } \\
\text { individuals' preferences } \\
\text { (SCHOR, BONOMO E } \\
\text { PEREIRA, 2004) }\end{array}$ & $\begin{array}{l}\text { 4. There is no economic theory that says what factors can be } \\
\text { correlated in the observed equation and to verify that that } \\
\text { equation really identifies the desirable factors. }\end{array}$ \\
\hline $\mathrm{OJ}$ & $\begin{array}{l}\text { 1. Analytic development of the } \\
\text { model. (OHLSON and } \\
\text { JUETTNER-NAUROTH, } \\
\text { 2005). } \\
\text { 2. Depends on fewer premises } \\
\text { than the other models. } \\
\text { 3. Uses accounting variables in its } \\
\text { formulation. (LOPES and } \\
\text { MARTINS, 2006). }\end{array}$ & $\begin{array}{l}\text { 1. It depends on the expectations, and for this reason uses } \\
\text { analysts' projections of the market as a proxy. } \\
\text { 5. Because it uses analysts' projections, which are } \\
\text { demonstrably optimistic, the result can be biased. }\end{array}$ \\
\hline
\end{tabular}

Source: Ohlson and Juettner-Nauroth (2005); Botosan and Plumlee (2000, p13); Roll (1997; Schor, Bonomo and Pereira (2004, p.55); Martins (2001); Lopes and Martins (2006). 
Having summarized these advantages and disadvantages, we now delineate the study itself.

\section{RESEARCH METHODOLOGY}

As seen above, there is a wide range of opinions in the accounting and financial literature regarding the best method for calculating the discount rates. One of the big problems in using this variable is that it is not observable, so it must be estimated.

For example, in the article by Botosan and Plumlee (2001), the authors used the Gordon \& Gordon model to compare the company disclosure level and expected cost of equity capital, while a year beforehand, the same authors, Botosan and Plumlee (2000) used the Ohlson model for the same purpose, and Botosan (1997) had already used the Ohlson model (first version) before this.

Other works, such as that of Chen, Chen and Wei (2003), have analyzed the relation between cost of equity capital (formulated by the OJ model), the level of company disclosure and their corporate governance level. To a certain extent there is a tendency among more recent authors to use the OJ model, since it is also more recent, contains accounting data in its formulation and has fewer premises than the other models. However, the question that can be raised is: If these authors had used other formulations for the discount rates, would their responses have been the same?

Similarly, Hail (2002), in a study that associates the cost of equity capital with companies' disclosure level, mentions using the Ohlson model for the cost of capital.

In Brazilian academic research in accounting and finance, the CAPM is the preferred method for estimating the cost of equity capital. One example is Alencar and Lopes (2004), who used beta from the CAPM to compare the level of disclosure and cost of equity capital. Their justification is that this beta represents the expected return, which is an ex-ante concept, representing a specific risk for a company, including the level of disclosure. Following the current international trend, Nakamura et al. (2006) applied the CAPM, the dividend discount model and the OJ model to estimate the cost of equity capital in their study on the impact of companies' disclosure on this cost.

In the line of empirical comparison of methods, Galdi and Lopes (2006) analyzed the results of the discounted cash flow model and the valuation model by residual earnings based on analysts' market projections, including discount rate projections (the majority of them carried out using the CAPM).

Perceiving the relevance of this subject to the academic and professional community and knowing that all research is done through a problem to be solved (GIL, 1999, p. 49), which according to Kerlinger $(1980$, p. 35) "is a question that shows a situation that needs discussion, investigation, decision or solution," we aimed in this work to respond to the following research problem:

Is there a significant difference among the cost of equity capital estimates based on different calculation methods?

Therefore, we formulated the following methodological hypothesis:

Methodological Hypothesis: No concern is necessary in choosing the suitable model to measure cost of equity capital, because all the models produce equal discount rates. 
Our initial sample was of companies making up part of the theoretical portfolio of the IBOVESPA on December 29, 2005. The table below identifies these firms and their respective shares.

Table 2: Research Sample

\begin{tabular}{|c|c|c|c|c|c|c|c|c|c|}
\hline N. & Ticker & Share & Type & Part.(\%) & N. & Ticker & Share & Type & Part.(\%) \\
\hline 1 & TNLP4 & TELEMAR & PN & 8.8936 & 30 & SDIA4 & SADIA S/A & PN N1 & 1.0556 \\
\hline 2 & PETR4 & PETROBRAS & PN & 7.6069 & 31 & BBAS3 & \begin{tabular}{|l|} 
BANCO DO \\
BRASIL \\
\end{tabular} & ON & 1.0136 \\
\hline 3 & VALE5 & VALE R DOCE & PNA N1 & 7.0467 & 32 & EMBR4 & EMBRAER & PN EJ & 0.9901 \\
\hline 4 & USIM5 & USIMINAS & PNA & 5.8371 & 33 & BRAP4 & BRADESPAR & PN N1 & 0.9667 \\
\hline 5 & GGBR4 & GERDAU & PN N1 & 4.6363 & 34 & ARCZ6 & ARACRUZ & \begin{tabular}{|l} 
PNB EJ \\
N1
\end{tabular} & 0.9572 \\
\hline 6 & CMET4 & CAEMI & PN & 4.0853 & 35 & BRTP4 & BRASIL T PAR & $\mathrm{PN} * \mathrm{~N} 1$ & 0.9354 \\
\hline 7 & CSNA3 & SID NACIONAL & ON & 3.9833 & 36 & SBSP3 & SABESP & $\begin{array}{l}\text { ON *EJ } \\
\text { NM }\end{array}$ & 0.9336 \\
\hline 8 & BBDC4 & BRADESCO & PN N1 & 3.7706 & 37 & CLSC6 & CELESC & PNB N2 & 0.8972 \\
\hline 9 & ELET6 & ELETROBRAS & PNB* & 3.2798 & 38 & ACES4 & ACESITA & PN & 0.8382 \\
\hline 10 & EBTP4 & EMBRATEL PAR & $\mathrm{PN} *$ & 2.9312 & 39 & TCOC4 & TELE CTR OES & $\mathrm{PN}$ & 0.8102 \\
\hline 11 & CMIG4 & CEMIG & $\mathrm{PN} * \mathrm{~N} 1$ & 2.5443 & 40 & TMCP4 & TELEMIG PART & $\mathrm{PN} *$ & 0.7691 \\
\hline 12 & ITAU4 & ITAUBANCO & PN EJ N1 & 2.4172 & 41 & PTIP4 & IPIRANGA PET & $\mathrm{PN}$ & 0.6303 \\
\hline 13 & BRTO4 & BRASIL TELEC & $\mathrm{PN} * \mathrm{~N} 1$ & 2.2032 & 42 & TLPP4 & TELESP & PN & 0.5609 \\
\hline 14 & PETR3 & PETROBRAS & ON & 1.9114 & 43 & TRPL4 & TRAN PAULIST & $\begin{array}{l}\text { PN *EJ } \\
\text { N1 } \\
\end{array}$ & 0.5499 \\
\hline 15 & VALE3 & VALE R DOCE & ON N1 & 1.8809 & 44 & ELPL4 & ELETROPAULO & $\mathrm{PN} * \mathrm{~N} 2$ & 0.5359 \\
\hline 16 & NETC4 & NET & PN N2 & 1.8464 & 45 & CRUZ3 & SOUZA CRUZ & ON EJ & 0.5289 \\
\hline 17 & BRKM5 & BRASKEM & PNA N1 & 1.8030 & 46 & CESP4 & CESP & PN * & 0.5112 \\
\hline 18 & ITSA4 & ITAUSA & PN EJ N1 & 1.5487 & 47 & EMBR3 & EMBRAER & ON EJ & 0.4702 \\
\hline 19 & UBBR11 & UNIBANCO & UNT N1 & 1.4761 & 48 & CRTP5 & CRT CELULAR & PNA & 0.4470 \\
\hline 20 & CPLE6 & COPEL & PNB* & 1.4679 & 49 & TLCP4 & TELE LEST CL & $\mathrm{PN}$ & 0.4347 \\
\hline 21 & TSPP4 & TELESP CL PA & PN & 1.4242 & 50 & CTAX4 & CONTAX & PN ED & 0.4197 \\
\hline 22 & TCSL4 & TIM PART S/A & $\mathrm{PN} *$ & 1.4076 & 51 & KLBN4 & KLABIN S/A & PN N1 & 0.4136 \\
\hline 23 & ELET3 & ELETROBRAS & $\mathrm{ON}^{*}$ & 1.4005 & 52 & CGAS5 & COMGAS & PNA* & 0.3890 \\
\hline 24 & AMBV4 & AMBEV & PN *EDJ & 1.3803 & 53 & BRTP3 & BRASIL T PAR & $\mathrm{ON} * \mathrm{~N} 1$ & 0.3757 \\
\hline 25 & GOAU4 & GERDAU MET & PN N1 & 1.2941 & 54 & TCSL3 & TIM PART S/A & $\mathrm{ON} *$ & 0.3496 \\
\hline 26 & ARCE3 & ARCELOR BR & ON N1 & 1.2641 & 55 & CMIG3 & CEMIG & $\mathrm{ON} * \mathrm{~N} 1$ & 0.2173 \\
\hline 27 & TMAR5 & TELEMAR N L & PNA EJ & 1.2421 & 56 & LIGH3 & LIGHT & $\begin{array}{l}\mathrm{ON}^{*} \\
\mathrm{NM}\end{array}$ & 0.1222 \\
\hline 28 & VCPA4 & V C P & PN EJ N1 & 1.1216 & 57 & CTAX3 & CONTAX & ON & 0.0676 \\
\hline 29 & TNLP3 & TELEMAR & ON & 1.1050 & & & & & \\
\hline
\end{tabular}

After analyzing this sample of companies and seeking the specific data, we perceived that for our purposes we could only use data on 34 companies, since some of the companies were not available in the database of ThomsonOneAnalytics ${ }^{7}$, or did not have a complete time series of returns.

Table 3 presents the means, standard deviations, medians and maximum and minimum values estimated by the models under analysis. The variable "apttbond" considers the APM formulation expressed in equation (10), using the risk-free rate as that on the American TBond; the variable "aptcbond" considers the same formulation using the Brazilian C-Bond; and the variable "aptsav" considers this formulation using the rate paid on guaranteed savings accounts in Brazil. The variable "gordon1B" represents the formulation presented in equation

\footnotetext{
${ }^{7}$ ThomsonOneAnalytics is an international database containing data on analysts' projections.
} 
(3), assuming a long-term growth rate of $6 \%$ a year; the variable "gordonl" represents the same formulation but with the long-term growth rate given by the result of regressing the growth of dividends projected by the analysts for the next three years; and the variable "gordon2" represents the formulation presented in equation (4). The variable "oj" is the result of the estimation carried out based on equation (12), considering a long-term growth rate of $6 \%$ a year. The variable "capmbr" represents the CAPM calculated with data from the Brazilian market; and the variable "capmus" refers to the same model based on the variables from the U.S. market (risk-free rate of return and expected market rate of return) plus the Brazil risk. Finally, the variable "capmbr5" represents the CAPM calculated with the data from the Brazilian market based on the returns of the past five years, and the variable CAPM does the same using the variables from the American market, adding the Brazil risk.

Table 3: Descriptive Statistics for the Costs of Equity Capital Calculated

\begin{tabular}{llllll}
\hline Variable & Mean & $\begin{array}{l}\text { Standard } \\
\text { Deviation }\end{array}$ & Median & Minimum & Maximum \\
\hline apttbond & 0.08302 & 0.00494 & 0.08227 & 0.07227 & 0.09391 \\
aptcbond & 0.10112 & 0.00494 & 0.10037 & 0.09037 & 0.11201 \\
aptsav & 0.10290 & 0.00494 & 0.10215 & 0.09214 & 0.11379 \\
gordon1b & 0.11224 & 0.03388 & 0.10805 & 0.06000 & 0.19079 \\
gordon1 & 0.18038 & 0.30099 & 0.08391 & -0.14116 & 1.25597 \\
gordon2 & 0.17364 & 0.22928 & 0.11401 & 0.00012 & 1.09319 \\
oj & 0.12407 & 0.05506 & 0.12696 & 0.01308 & 0.26541 \\
capmbr & 0.37476 & 0.07208 & 0.37970 & 0.11382 & 0.51667 \\
capmus & 0.08259 & 0.00306 & 0.08302 & 0.07214 & 0.08879 \\
capmbr5 & 0.23460 & 0.04797 & 0.22845 & 0.13882 & 0.31808 \\
capmus5 & 0.02630 & 0.02750 & 0.01964 & -0.04970 & 0.08435 \\
\hline
\end{tabular}

It can be seen that the largest deviations come from the results of the "gordonl model (without establishing a fixed growth rate) and "gordon2" model. The other variables demonstrate a more standardized behavior, but still with relevant differences between some results. One result that stands out is the large disparity between the CAPM calculated based on the expected return of the Brazilian market, "capmbr", in relation to "capmus", which considers the risk premium based on the variables in the U.S. market, adding the Brazil risk at the end of the calculation.

The use of the IBrX in 2005 (a very good year for the Brazilian market) as the expected return for the Brazilian capital market affects the result of the "capmbr", putting it way above the normal market rates. Additionally, the disparity between the "capmbr5" and "capmus5" can be explained by the negative average return in the period of the S\&P 500 index, representing companies listed on the NYSE. In this context, if the analysis of the expected returns were conducted based on historic data from the past five years, the risk premium would become negative, thus affecting the expected return.

To give a better understanding of the relationship among the variables, Table 4 presents the result of the Pearson correlations for the variables under study. It shows there are some negative correlations, which is contrary to the theory that the expected result for the cost of capital should not be different just because of using different models. However, it should be noted that only some of the correlations between the models are negative, and among these few are significant at the $5 \%$ or $1 \%$ levels, which is in line with the theoretical structure of the models. Hence, when the cost of capital increases for one of the models, the impact in another model will also be positive. 
Table 4: Correlation of the Variables under Analysis

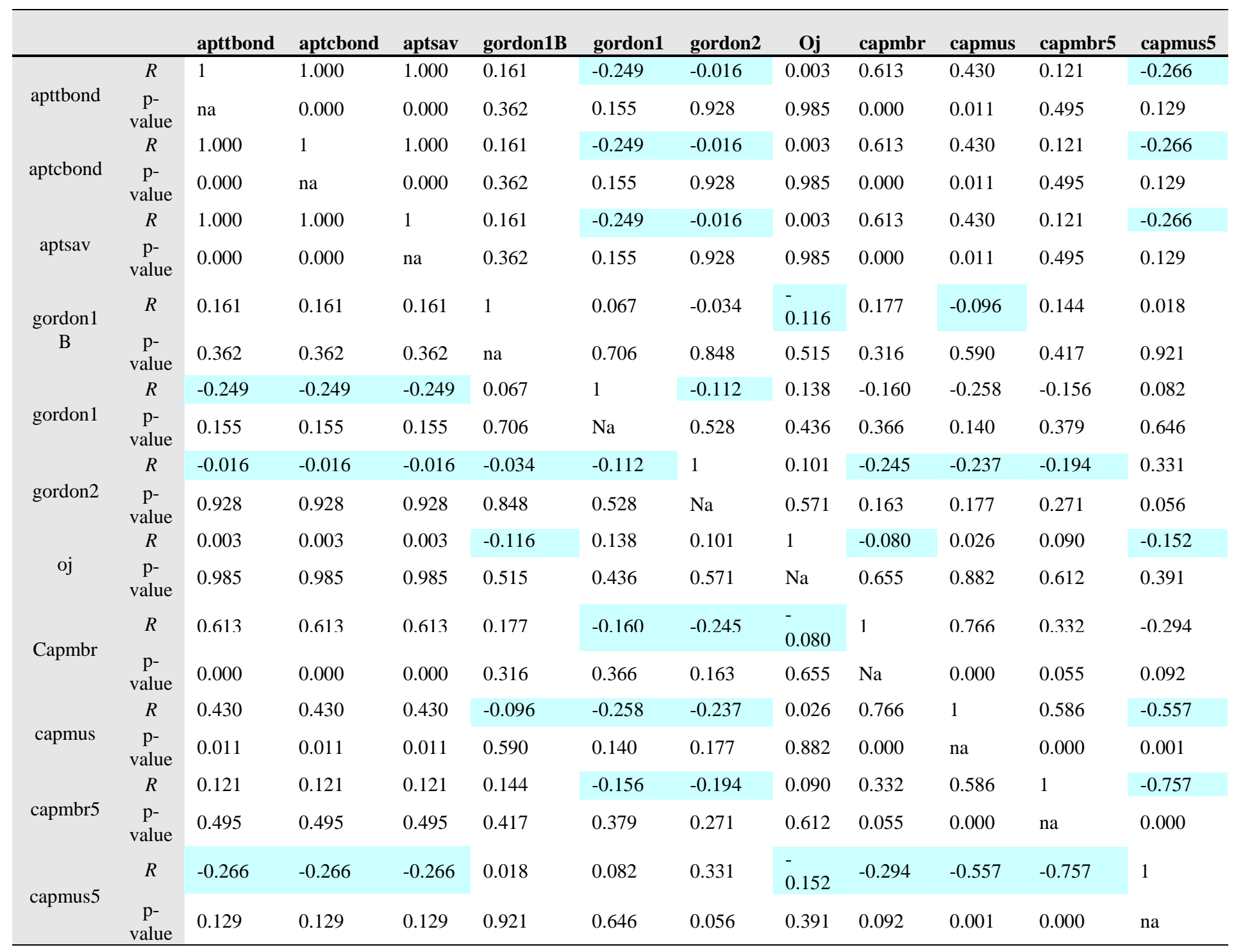

At this point it is essential to understand the difference among the models more deeply. To elucidate this, we used difference of means tests to compare all the models, pairwise, attempting to identify differences between them.

We used the hypotheses below to carry out this pair-wise comparison.

$$
\boldsymbol{H}_{0}: \mu_{1}-\mu_{2}-\ldots-\mu_{n}=\mathbf{0}
$$

The null hypothesis, as demonstrated above, infers that the mean of the indices calculated in one form is equal to the mean of the same indices calculated in another form, and so on.

In this type of test, the means are paired, because what is being compared is the same variable, "cost of equity capital", only calculated based on different measurement methods.

For analysis of two paired means, the $\mu_{n}$ is removed from the formula and the following null hypothesis is used:

$\boldsymbol{H}_{0}: \mu_{1}-\mu_{2}=\mathbf{0}$ 
After calculating the cost of capital estimates, we ascertained the differences between the results obtained using each of the models. We used the Kruskal-Wallis (nonparametric) test, which tests together whether $\mathrm{k}$ independent samples come from the same population, and the parametric difference of means test.

We considered a 5\% probability of the occurrence of a type 1 error, i.e., rejecting the null hypothesis when it is really true. To adequately apply the parametric paired-means test, the variables must be normally distributed. To discover this, we used the KolmogorovSmirnov test.

According to Siegel (1956, pp. 46-52), the null hypothesis of the Kolmogorov-Smirnov test posits that the differences between the accumulated frequency distribution of a random sample of $\mathrm{N}$ observations, $\mathrm{F}_{0}(\mathrm{X})$, and the theoretical distribution under $\mathrm{H}_{0}$ (in this case the normal distribution), $\mathrm{F}_{\mathrm{e}}(\mathrm{X})$, are small and within the limits of random errors. We performed the Kolmogorov-Smirnov test at a 95\% level of confidence $(\alpha=5 \%)$. The null hypothesis is $H_{0}$ : the variable follows a normal distribution. The results obtained with this test are in Table 5.

Table 1: Test of Normality of the Variables

\begin{tabular}{|c|c|c|c|c|c|c|c|c|c|c|c|}
\hline \multicolumn{12}{|c|}{ Kolmogorov-Smirnov Test } \\
\hline & apttbond & aptcbond & aptsav & $\begin{array}{c}\text { gordon1 } \\
\text { B }\end{array}$ & gordon1 & gordon2 & $\mathbf{o j}$ & capmbr & capmus & capmbr 5 & capmus5 \\
\hline $\mathrm{P}$ & & & & & & & 0.89 & & & & \\
\hline & 0.653 & 0.653 & 0.653 & 0.820 & 0.016 & 0.001 & & 0.625 & 0.590 & 0.492 & 0.391 \\
\hline
\end{tabular}

The results of the Kolmogorov-Smirnov test indicated not rejecting the normality of the variables for the majority of the models, with the exception of "gordonl" and "gordon2". We now present the results of the difference of means test.

\section{RESULTS}

We first ran the Kruskal-Wallis test, which tests the joint hypothesis of equality of the means. By this, we tested whether the means ascertained by the Gordon, CAPM, APM and OJ methods are statistically equal. The test hypotheses are:

$$
\begin{aligned}
& H_{0}: \mu_{\text {gordon }}=\mu_{\text {capm }}=\ldots . .=\mu_{o j}=\mu_{\text {apm }} \\
& H_{1}: \text { at least one of the means is different }
\end{aligned}
$$

Table 6 shows the results of the Kruskal-Wallis test.

Table 2: Kruskal-Wallis Test

\begin{tabular}{ll}
\hline Test Statistics (a,b) & $\mathrm{Ke}$ \\
\hline & 236.645 \\
Chi-Square & 10 \\
g.l. & 0.000 \\
p-value & \\
\hline
\end{tabular}

The results presented in Table 6 did not permit us to say that the costs of capital calculated based on the different models have equal means. Thus, the pairwise parametric analysis of the models was indicated, except for the "aptcbond" model (because it presented 
the same nature and had correlation of 1 with "apttbond", making its analysis in this respect redundant). We should stress that we also did not conduct the test for the "gordonl" and "gordon2" models, since these were not accepted by the normality test.

We now use the test of paired difference of means (parametric). The results are detailed in Table 7.

Since the number of variables under analysis is 8 , we have $\left(\begin{array}{c}8 \\ 2\end{array}\right)$ combinations, or 28 combinations between the variables/models. The shaded rows represent the models to which a statistically significant difference cannot be attributed (at 1\%) between their mean results. These models, then, can be said to be equivalent for the calculation of cost of equity capital.

Table 3: Parametric Difference of Means Tests (pairwise)

\begin{tabular}{|c|c|c|c|}
\hline & Mean & Standard Deviation & $P$ value (2-tailed) \\
\hline apttbond - aptsav & -0.0199 & 0.0000 & 0.0000 \\
\hline apttbond - gordon1B & -0.0292 & 0.0334 & 0.0000 \\
\hline apttbond - oj & -0.0410 & 0.0553 & 0.0001 \\
\hline apttbond - capmbr & -0.2917 & 0.0692 & 0.0000 \\
\hline apttbond - capmus & 0.0004 & 0.0046 & 0.5812 \\
\hline apttbond - capmbr5 & -0.1516 & 0.0476 & 0.0000 \\
\hline apttbond - capmus5 & 0.0567 & 0.0292 & 0.0000 \\
\hline aptsav - gordon1B & -0.0093 & 0.0334 & 0.1126 \\
\hline aptsav - oj & -0.0212 & 0.0553 & 0.0324 \\
\hline aptsav - capmbr & -0.2719 & 0.0692 & 0.0000 \\
\hline aptsav - capmus & 0.0203 & 0.0046 & 0.0000 \\
\hline aptsav - capmbr5 & -0.1317 & 0.0476 & 0.0000 \\
\hline aptsav - capmus5 & 0.0766 & 0.0292 & 0.0000 \\
\hline gordon $1 \mathrm{~B}-\mathrm{oj}$ & -0.0118 & 0.0679 & 0.3172 \\
\hline gordon1B - capmbr & -0.2625 & 0.0740 & 0.0000 \\
\hline gordon1B - capmus & 0.0297 & 0.0343 & 0.0000 \\
\hline gordon1B - capmbr5 & -0.1224 & 0.0546 & 0.0000 \\
\hline gordon1B - capmus5 & 0.0859 & 0.0433 & 0.0000 \\
\hline oj - capmbr & -0.2507 & 0.0941 & 0.0000 \\
\hline oj - capmus & 0.0415 & 0.0551 & 0.0001 \\
\hline oj - capmbr5 & -0.1105 & 0.0697 & 0.0000 \\
\hline oj - capmus5 & 0.0978 & 0.0652 & 0.0000 \\
\hline capmbr - capmus & 0.2922 & 0.0698 & 0.0000 \\
\hline capmbr - capmbr5 & 0.1402 & 0.0721 & 0.0000 \\
\hline capmbr - capmus5 & 0.3485 & 0.0844 & 0.0000 \\
\hline capmus - capmbr5 & -0.1520 & 0.0462 & 0.0000 \\
\hline capmus - capmus5 & 0.0563 & 0.0293 & 0.0000 \\
\hline capmbr5 - capmus5 & 0.2083 & 0.0711 & 0.0000 \\
\hline
\end{tabular}

The results shown in Table 7 demonstrate that the CAPM and APM, based on American market data, result in statistically similar values. Additionally, the Gordon and OJ models result in equal mean values, with the greatest significance being between the "gordon $1 B$ " and "oj" models. A detail that calls attention is the statistically significant difference between the means of the values calculated by the CAPM based on the American data plus the Brazil risk in relation to the CAPM calculated directly from Brazilian market data. 
In this context, the evidence indicates that the greater subjectivity of the variables that compose the CAPM make it more sensitive in relation to the variations of its formulation than the models based on earnings and dividends projections, notably the OJ and Gordon models.

Just as there are parametric tests of the means, there are nonparametric ones as well. The latter tests do not have premises in their usage, in contrast with the former, and for this reason are said to be more fragile. Despite this stereotype of fragility, nonparametric tests are more robust in the absence of normality and homoskedasticity. Another reason to use nonparametric tests is to observe if their results are the same as those obtained with parametric tests, i.e., as a confirmation tool. With this in mind, we applied the Wilcoxon nonparametric means test.

In the nonparametric tests, we used all the variables, as can be seen in the table below.

Table 4: Nonparametric Difference of Means Tests (pairwise)

\begin{tabular}{|c|c|c|c|c|c|c|c|c|c|}
\hline \multicolumn{2}{|l|}{ Pairs } & $\mathbf{Z}$ & & Pairs & $\mathbf{Z}$ & $\begin{array}{c}\text { Valor } \\
\mathbf{p}\end{array}$ & Pairs & $\mathbf{Z}$ & $P$ value \\
\hline $\begin{array}{l}\text { aptsav } \\
\text { apttbond }\end{array}$ & - & -5.391 & 0.000 & $\begin{array}{l}\text { gordon1B - } \\
\text { aptsav }\end{array}$ & -1.530 & 0.126 & $\begin{array}{l}\text { capmus } \\
\text { gordon1 }\end{array}$ & -1.068 & 0.285 \\
\hline $\begin{array}{l}\text { gordon1B } \\
\text { apttbond }\end{array}$ & - & -3.889 & 0.000 & $\begin{array}{l}\text { gordon1 - } \\
\text { aptsav }\end{array}$ & -0.299 & 0.764 & $\begin{array}{l}\text { capmbr5 } \\
\text { gordon1 }\end{array}$ & -2.658 & 0.007 \\
\hline $\begin{array}{l}\text { gordon1 } \\
\text { apttbond }\end{array}$ & - & -1.000 & 0.317 & $\begin{array}{ll}\text { gordon2 - } \\
\text { aptsav }\end{array}$ & -2.265 & 0.023 & $\begin{array}{l}\text { capmus5 } \\
\text { gordon1 }\end{array}$ & -3.513 & 0.000 \\
\hline $\begin{array}{l}\text { gordon } 2 \\
\text { apttbond }\end{array}$ & - & -3.718 & 0.000 & oj-aptsav & -2.060 & 0.039 & $\begin{array}{l}\text { Oj } \\
\text { gordon2 }\end{array}$ & -0.470 & 0.638 \\
\hline oj - apttbon & & -3.547 & 0.000 & $\begin{array}{l}\text { capmbr } \\
\text { aptsav }\end{array}$ & -5.086 & 0.000 & $\begin{array}{l}\text { capmbr } \\
\text { gordon2 }\end{array}$ & -3.940 & 0.000 \\
\hline $\begin{array}{l}\text { capmbr } \\
\text { apttbond }\end{array}$ & - & -5.086 & 0.000 & $\begin{array}{l}\text { capmus } \\
\text { aptsav }\end{array}$ & -5.086 & 0.000 & $\begin{array}{l}\text { capmus } \\
\text { gordon2 }\end{array}$ & -3.718 & 0.000 \\
\hline $\begin{array}{l}\text { capmus } \\
\text { apttbond }\end{array}$ & - & -0.538 & 0.590 & $\begin{array}{l}\text { capmbr5 - } \\
\text { aptsav }\end{array}$ & -5.086 & 0.000 & $\begin{array}{l}\text { capmbr5 } \\
\text { gordon2 }\end{array}$ & -3.940 & 0.000 \\
\hline $\begin{array}{l}\text { capmbr5 } \\
\text { apttbond }\end{array}$ & - & -5.086 & 0.000 & $\begin{array}{ll}\text { capmus5 - } \\
\text { aptsav }\end{array}$ & -5.086 & 0.000 & $\begin{array}{l}\text { capmus5 } \\
\text { gordon2 }\end{array}$ & -5.017 & 0.000 \\
\hline $\begin{array}{l}\text { capmus5 } \\
\text { apttbond }\end{array}$ & - & -5.017 & 0.000 & $\begin{array}{ll}\text { gordon1 } & - \\
\text { gordon1B }\end{array}$ & -0.145 & 0.884 & capmbr - oj & -5.069 & 0.000 \\
\hline $\begin{array}{l}\text { aptsav } \\
\text { aptcbond }\end{array}$ & - & -5.391 & 0.000 & $\begin{array}{l}\text { gordon2 } \\
\text { gordon1B }\end{array}$ & -1.205 & 0.228 & capmus - oj & -3.564 & 0.000 \\
\hline $\begin{array}{l}\text { gordon1B } \\
\text { aptcbond }\end{array}$ & - & -1.855 & 0.063 & $\begin{array}{l}\text { oj } \\
\text { gordon1B }\end{array}$ & -0.726 & 0.467 & $\begin{array}{l}\text { capmbr5 - } \\
\text { oj }\end{array}$ & -4.915 & 0.000 \\
\hline $\begin{array}{l}\text { gordon1 } \\
\text { aptcbond }\end{array}$ & - & -0.333 & 0.738 & $\begin{array}{l}\text { capmbr } \\
\text { gordon1B }\end{array}$ & -5.086 & 0.000 & $\begin{array}{l}\text { capmus5 - } \\
\text { oj }\end{array}$ & -4.881 & 0.000 \\
\hline $\begin{array}{l}\text { gordon } 2 \\
\text { aptcbond }\end{array}$ & - & -2.419 & 0.015 & $\begin{array}{l}\text { capmus } \\
\text { gordon1B }\end{array}$ & -3.872 & 0.000 & $\begin{array}{l}\text { capmus } \\
\text { capmbr }\end{array}$ & -5.086 & 0.000 \\
\hline oj-aptcbon & & -2.214 & 0.026 & $\begin{array}{l}\text { capmbr5 - } \\
\text { gordon1B }\end{array}$ & -5.086 & 0.000 & $\begin{array}{l}\text { capmbr5 - } \\
\text { capmbr }\end{array}$ & -5.034 & 0.000 \\
\hline $\begin{array}{l}\text { capmbr } \\
\text { aptcbond }\end{array}$ & - & -5.086 & 0.000 & $\begin{array}{l}\text { capmus5 - } \\
\text { gordon1B }\end{array}$ & -5.086 & 0.000 & $\begin{array}{l}\text { capmus5 - } \\
\text { capmbr }\end{array}$ & -5.086 & 0.000 \\
\hline $\begin{array}{l}\text { capmus } \\
\text { aptcbond }\end{array}$ & - & -5.086 & 0.000 & $\begin{array}{l}\text { gordon2 - } \\
\text { gordon1 }\end{array}$ & -0.580 & 0.561 & $\begin{array}{l}\text { capmbr5 - } \\
\text { capmus }\end{array}$ & -5.086 & 0.000 \\
\hline $\begin{array}{l}\text { capmbr5 } \\
\text { aptcbond }\end{array}$ & - & -5.086 & 0.000 & oj - gordon1 & -0.128 & 0.898 & $\begin{array}{l}\text { capmus5 - } \\
\text { capmus }\end{array}$ & -5.034 & 0.000 \\
\hline $\begin{array}{l}\text { capmus5 } \\
\text { aptcbond }\end{array}$ & - & -5.086 & 0.000 & $\begin{array}{l}\text { capmbr - } \\
\text { gordon1 }\end{array}$ & -3.513 & 0.000 & $\begin{array}{l}\text { capmus5 - } \\
\text { capmbr5 }\end{array}$ & -5.086 & 0.000 \\
\hline
\end{tabular}

It is interesting to note in Table 8 that the tests that gave equal means in Table 7 were confirmed by the nonparametric test. It can also be seen that the Gordon 1, Gordon 1B, 
Gordon 2 and OJ models had good acceptance in the tests of mutual equalities and equalities with the other models.

\section{CONCLUSIONS}

This work investigated the models for estimating the cost of equity capital and their respective results based on empirical data with the intention of responding to the following research question: Is there a significant difference among the values estimated for the cost of equity capital using different calculation methods?

In this context, we used the Gordon, CAPM, APM and OJ models and some different specifications of each type (referring to the Gordon, CAPM and APM).

The results do not permit saying that the choice of model is indifferent in relation to the outcome of estimating the cost of equity capital. Besides this, it can be said that the methodological hypothesis was rejected, and there are differences from selecting a model to measure the cost of equity capital, because the models demonstrate different discount rates when examined in their total.

We also used paired tests (parametric and nonparametric) to verify the equality between the pair-wise means. The models that most stood out were Gordon, modified Gordon and OJ.

So in many cases there are significant differences in means for each type of model. The evidence indicate that due to its more subjective structure, the CAPM is the most sensitive model to variations in its formulation. In reality, both the CAPM and APM have very strong subjective values, besides having technical problems when applied in a developing country like Brazil, whose capital market is not as developed and efficient as in more advanced countries such as the United States.

The models based on earnings and dividends projections, notably the OJ and Gordon models, resulted in mutuallyequivalent mean values when the premises used were the same. It is important to comment on the theoretical superiority of the OJ model, given that it was developed with fewer premises and in a more analytic manner when compared with the Gordon and Gordon \& Gordon models. This is perhaps one of the explanations for the growing acceptance of the OJ model in international works on cost of equity capital.

Although the results and conclusions here have important implications, some limitations of the study must be pointed out, namely that the conclusions obtained are restricted to the sample studied and the variables and the statistical tools used. This points to new research opportunities applying other statistical tools to different variables in comparison to those of the present work.

\section{REFERENCES}

ALENCAR, R.C.; LOPES, A.B. Custo de capital próprio e nível de disclosure nas empresas brasileiras. In: $5^{\circ}$ Congresso USP de Controladoria e Contabilidade. Anais. Universidade de São Paulo: October 2005.

ARAÚJO, P.A.B., Verificação da eficácia do modelo de precificação de ativos financeiros no processo de avaliação das empresas brasileiras privatizadas. São Paulo: FEA/USP, 1996. MBA Dissertation, Faculdade de Economia, Administração e Contabilidade da Universidade de São Paulo, 1996. 
BERNSTEIN, L.A., and WILD, J.J. Financial Statement Analysis: Theory, Application and Interpretation. New York: McGraw-Hill Irwin, 1997.

BOTOSAN, Christine. Disclosure Level and the Cost of Equity Capital. Accounting Review. 72. 323-349. 1997.

. Disclosure Level and Expected Cost of Equity Capital: An Examination of Analysts' Rankings of Corporate Disclosure. January 2000. Available at: http://ssrn.com/abstract = 208148. Accessed on August 7, 2006.

BOTOSAN, C. and PLUMLEE, M. Disclosure level and expected cost of equity capital: an examination of analysts' rankings of corporate disclosure. Working paper, 2001. University of Utah Working Paper. Available at: http://ssrn.com/abstract=279309. accessed on August 7, 2006.

COPELAND, T., KOLLER, T. and MURRIN, J. Valuation: measuring and managing the value of companies. New York: Wiley, 2000.

DAMODARAN, A. Avaliação de Investimentos: ferramentas e técnicas para a determinação do valor de qualquer ativo. Rio de Janeiro: Qualimark,1997.

GIL, Antonio C. Métodos e técnicas de pesquisa social. São Paulo: Atlas, 1999.

GALDI, F.C., LOPES, A.B. Análise Empírica de Modelos de Valuation no Ambiente Brasileiro: Fluxo de Caixa Descontado versus Modelo de Ohlson. In: $30^{\circ}$ Encontro da ANPAD. Anais.Salvador: September 2006.

GARCIA, R.; BONOMO, M. Tests of conditional asset pricing models in the Brazilian stock market. Journal of International Money and Finance, v. 20, p. 71-90, 2001.

GORDON, J. and GORDON, M. The finite horizon expected return model. Financial Analysts Journal, May-June 1997, pp. 52-61.

GORDON, J. The investment, financing and valuation of the corporation. Homewood, Il: Irwin, 1962.

GORDON, J. The pricing of risk in common shares. International Review of Financial Analysis, 1993, pp. 147-153.

GREGÓRIO, J. Análise comparativa da rentabilidade do setor bancário privado atuante no Brasil no período de 1997 a 2004. São Paulo: FEA/USP, 2005. Master's Dissertation in Control and Accountancy, Faculdade de Economia, Administração e Contabilidade da Universidade de São Paulo, 2005.

HAIL, Luzi. The impact of voluntary corporate disclosures on the ex-ante cost of capital for Swiss firms. The European Accounting Review. Vol 11, Num. 4, pp. 741-773. 2002.

KERLINGER, Fred N. Metodologia da pesquisa em ciências sociais: um tratamento conceitual. São Paulo: EPU, 1980. 
LIMA, G. A. S. F. de. Governança Corporativa e Hipótese de Mercados Eficientes: O estudo do anúncio da emissão de American Depositary Receitps (ADRs) com a utilização de estudos de eventos. São Paulo: FEA/USP, 2005. Master's Dissertation in Control and Accountancy, Faculdade de Economia, Administração e Contabilidade da Universidade de São Paulo, 2005.

LOPES, Alexsandro B.; Martins, Eliseu. Teoria da Contabilidade: Uma nova Abordagem. São Paulo: Atlas, 2006.

MARKOWITZ, H. Portfolio Selection. Journal of Finance 7. 1952, pp. 77-91.

MARTINS, Eliseu. Avaliação de empresas: Da mensuração Contábil à Econômica. São Paulo: Atlas, 2001.

NAKAMURA, W.T., GOMES, E.A., ANTUNES, M.T.P., MARÇAL, E. F. Estudo sobre os Níveis de Disclosure Adotados pelas Empresas Brasileiras e seu Impacto no Custo de Capital. In: 30 Encontro da ANPAD. Anais.Salvador: September 2006.

OHLSON, J.A. On accounting based valuation formulae. Review of Accounting Studies 10. 2005, pp.323-347.

OHLSON, J.A., and JUETTNER-NAUROTH, B.E. Expected EPS and EPS Growth as Determinants of Value. Review of Accounting Studies 10. 2005, pp.349-365.

PALEPU, K.G., HEALY, P.G., e BERNARD, V. L. Business Analysis and Valuation: Using Financial Statements. 3rd ed. Ohio: South-Western College Publishing, 2004.

PENMAN, S. H. Financial Statements Analysis and Security Valuation. New York: McGrawHill, 2001.

REILLY, Frank K.; BROWN, Keith C. Investment Analysis and Portfolio Management. 7th ed. Ohio: Thomson Learning South-Western, 2003.

ROSS, S.A.; RANDOLPH, W.W.; JAFFE, J.F. Administração Financeira: Corporate Finance. São Paulo, Ed. Atlas: 1995.

SCHOR, Adriana; BONOMO, Marco; PEREIRA, Pedro L. V. APT e Variáveis macroeconômicas: um estudo empírico sobre o mercado acionário brasileiro. In: Finanças Aplicadas ao Brasil. BONOMO, Marco (Org.). 2nd ed. Rio de Janeiro: Editora FGV, 2004.

SIEGEL, S. Nonparametric Statistics for the Behavioral Sciences. New York: McGraw-Hill, 1956.

WHITE, G.I., SONDHI, A.C., and FRIED, D. The Analysis and Use of Financial Statements. 3rd ed., New York: John Wiley \& Sons, 2003. 